Amil T. Aghayev*

\title{
Assessment of the 2010 Kura River Flood Using Remote Sensing Data and GIS Tools
}

\section{Introduction}

Floods are among the most devastating natural hazards in the world, leading to significant economic and social damages than any other natural phenomenon [7]. Even a minor flood can cause great damage to urban and socio-economic infrastructure [3]. Geographic information systems (GIS), with their ability to combine information from a variety of sources such as maps, computer models and remotely sensed imagery, can be useful tools in understanding the patterns and potential effects of hazards. GIS is a versatile tool, allowing it to play a supportive role during many stages of mitigation planning [22].

Remote sensing and GIS technologies provide fundamental tools for observing and investigating the dynamics of various phenomena. Spatial data, in particular Digital Elevation Models and land use data sets are frequently used for map flood risk areas [18]. Satellite remote sensing is a valuable tool for flood monitoring and it can become a helpful instrument in flood management and alleviation [15, 16]. Key advantages of remote sensing include its relatively low or no acquisition costs allowing the mapping of large, often otherwise inaccessible regions [20].

Floods are one of most frequently occurring natural phenomena in Azerbaijan and cause great damage and losses to people, infrastructure, and the whole economy of the country. In particular, devastating floods occur on the Kura and the Aras rivers, the two longest rivers in the country, with a severe impact on lowlands around the Caspian Sea, along the lower reach of the Kura River. The most recent devastating flood disaster on the Kura and Aras took place in 2010. This flood differed noticeably from past flood events due to its scale. Importantly, areas inundated during the flood and damage mapped in subsequent assessments were shown differently in various sources $[6,11]$. Therefore, the aim of this study was to test freely available satellite data in 2010 Kura flood extent mapping, comparing the results to existing flood data sets.

* National Aviation Academy, Department of Aerospace Monitoring of Environment, Baku, Azerbaijan; Jagiellonian University in Kraków, Institute of Geography and Spatial Management, Department of Geographical Information Systems, Cartography and Remote Sensing, Krakow, Poland 


\section{Study Area Description}

The plains around and east of the junction of Kura and Aras rivers were selected as a study area (Fig. 1). The reason to select this area for study is the historically regular flood occurrence.

The Kura river has $1515 \mathrm{~km}$ and the basin area is 188 thousand $\mathrm{km}^{2}$ (Fig. 1). The river rises in the north-eastern slope of Gizilgadik mountain of Kars Upland in Turkey (2740 $\mathrm{m}$ a.s.1.) [2].

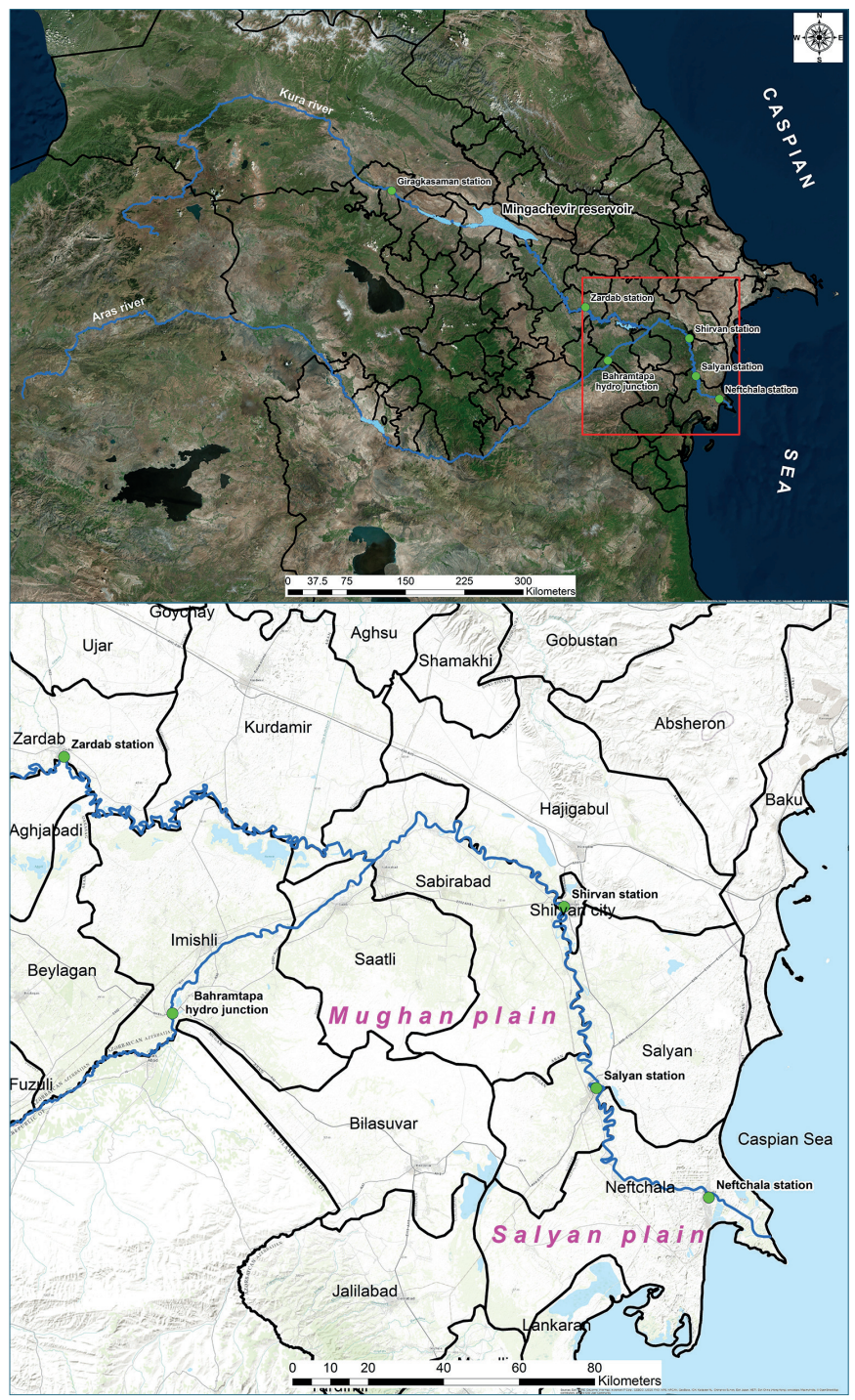

Fig. 1. Study area 
According to the annual flow regime, the Kura River has a typical spring abundance water and a relatively weak autumn discharge [5]. Basically, the Kura River is nourished with snowmelt, groundwater, rain, and glacier water [19].

The length of the Aras River is $1072 \mathrm{~km}$ and the basin area is 102 thousand $\mathrm{km}^{2}$. The source of the river lies on the slopes of Bingol ridge, Turkey (approximately $3000 \mathrm{~m}$ a.s.l) (Fig. 1) [4, 5]. The Aras River flows from volcanic plateaus and its annual flow consists of groundwater, snowmelt and rain waters [10]. The Aras joins the Kura $200 \mathrm{~km}$ west from the Caspian Sea, at an altitude of $-14 \mathrm{~m}$ a.s.l. in Sabirabad district.

\subsection{Historical Floods in the Kura Basin}

Large basin, landscape structure, hydro-meteorological and soil conditions of the Kura River, as well as the presence of a large number of tributaries of the river often creates unexpected flood threat. For its hazardous and sudden floods, the local population called the river "Crazy Kura", sometimes "Bloody Kura" [2].

Historically, floods in the downstream of the Kura River were observed regularly, but written records only cover the period after 1858 . Historical sources provide wide information about floods of the Kura and Aras Rivers causing natural disaster in 1921, 1929, 1931, 1932, 1936, 1937, 1938, 1940, 1942, 1944, 1967, 1969, 1976, 1979, 1982, 1989, 1997, 2002, 2003, 2006, 2007, 2010 too [2]. Devastating floods that caused damage occurred in this part of the Kura River basin also in the nineteenth century. The stream that depleted the soil barrier on the right bank of the Aras River in 1896 near the Saatli settlement created the so-called New Aras tributary. Not only the Mughan plain, but also the south-eastern parts of the Salyan plain including the 160000 hectares were under floodwaters. The Kura River flood that occurred in May, 1915 was one of the most hazardous floods over 150 years (Fig. 2).

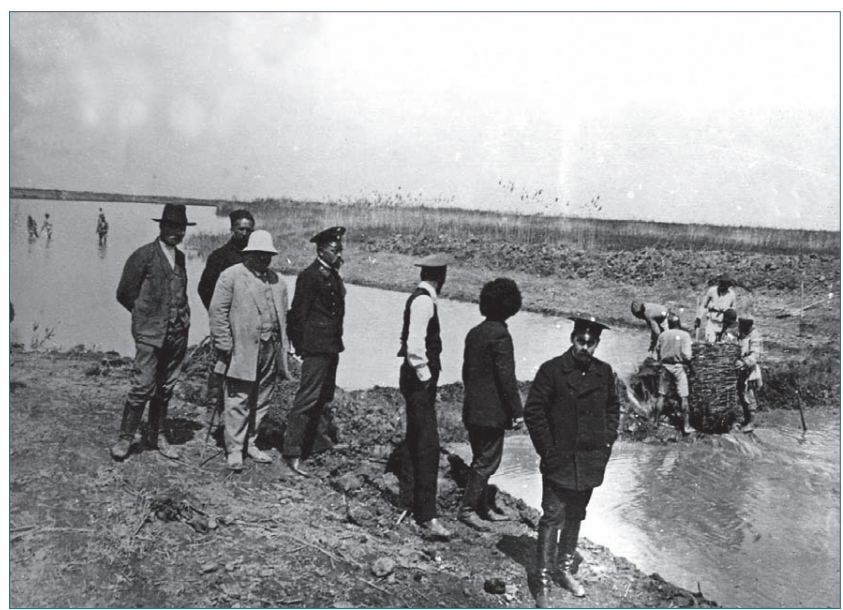

Fig. 2. Protected cropped land from floodwaters in 1915 Source: [21] 
A large territory in the Shirvan plain were inundated by floodwaters which destroyed coastal barriers in several towns and riverside villages. The flood waters covered more than 200,000 hectares in area, flowing out through the left bank of the Kura River and running into the river near Shirvan settlement again [2].

\subsection{Factors Forming the 2010 Kura River Flooding}

The Kura River flood that occurred in May, 2010 in Azerbaijan territory differed from previous floods. The main reasons for the flooding were consistent heavy rains at the same time in Turkey and Georgia, as well as in the territory of Azerbaijan. Extreme water level rising destroyed embankments in many regions at the same time, and flowed to the areas with a low level from the river mouth [2] (Fig. 3).

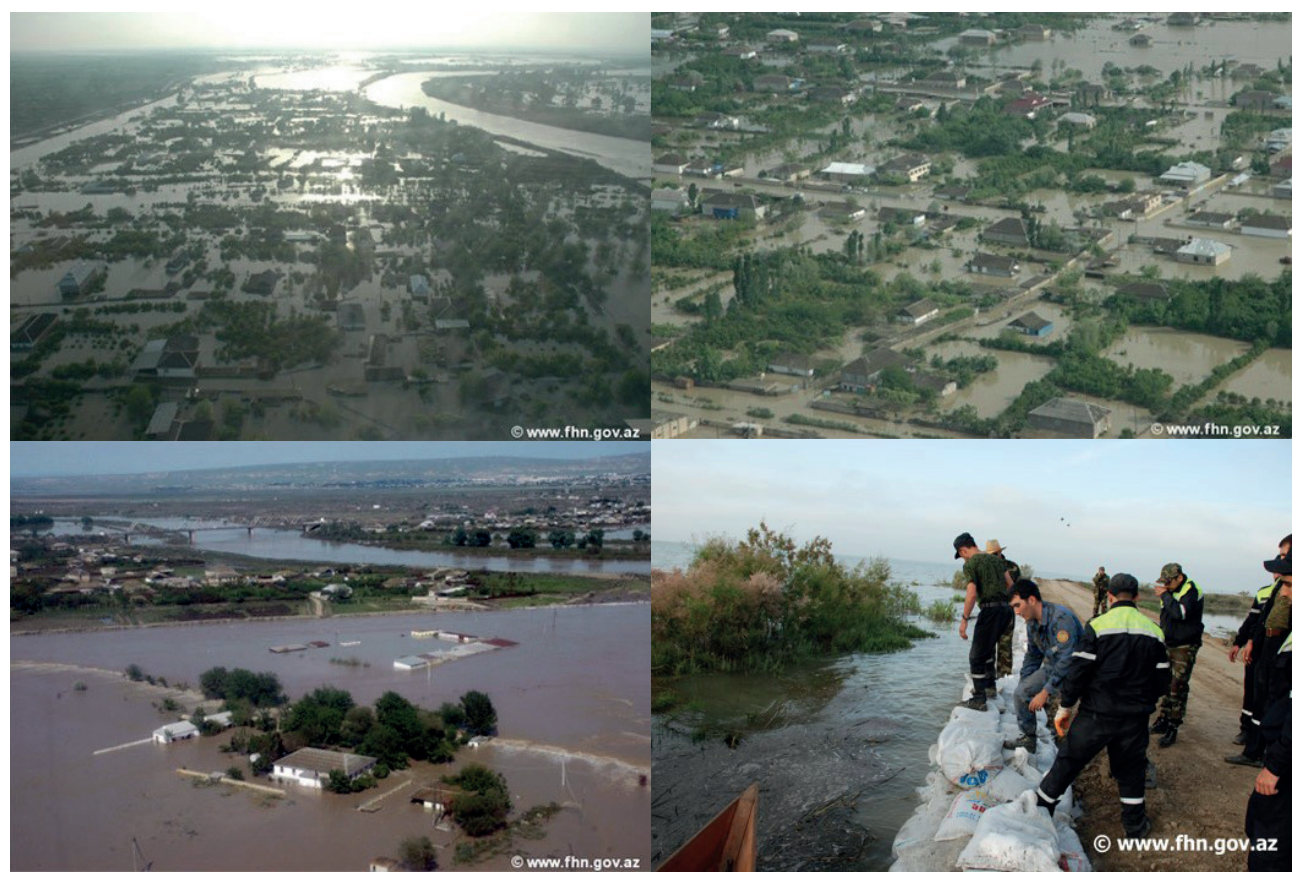

Fig. 3. Inundated areas during 2010 flood

Source: [9]

According to the hydrometeorogical data, comparing with previous years, the amount of precipitation in 2010 was higher up to 1.1 than the perennial norm (Fig. 4). For that reason, sharp increase of the water regime in rivers was observed (Fig. 5) [17].

For the regulation of the water consumption in the Kura River, the possibilities of the Mingachevir water reservoir was utulized and water collection almost reached to the maximum level (Fig. 6). At the same time, the dam of the reservoir faced with the threat of destruction and therefore there was the need to release excess water. 


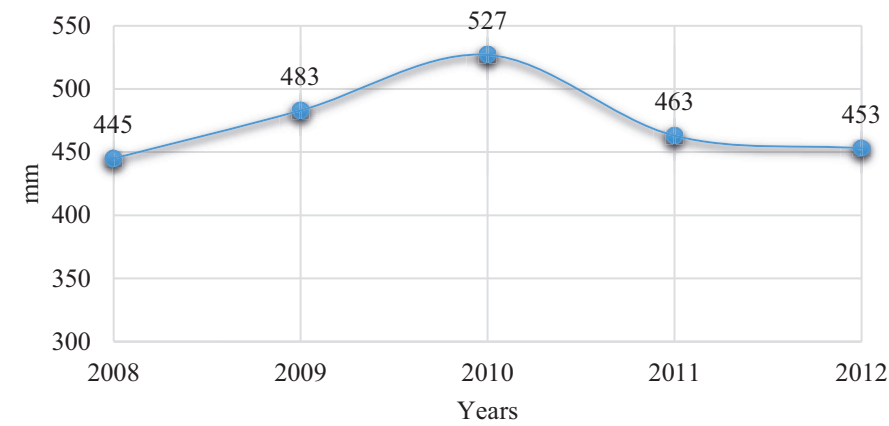

Perrenial norm 1961-1990: 477 mm

Fig. 4. Annual average precipitation during 2008-2012 in Azerbaijan

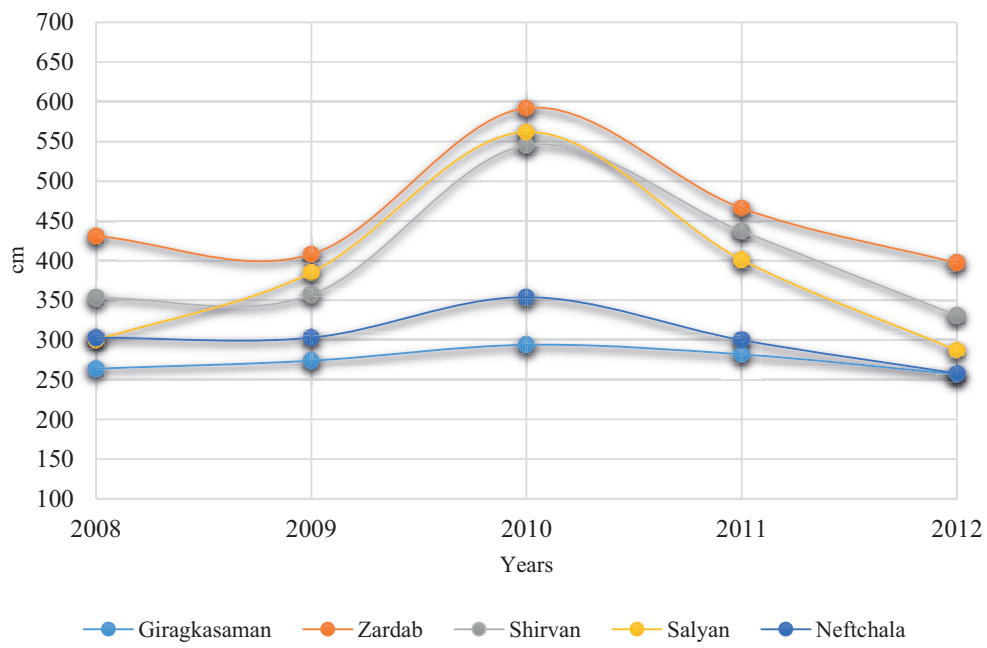

Fig. 5. The tendency of change of the average annual water level in the Kura River in for the period of 2008-2012 over different stations

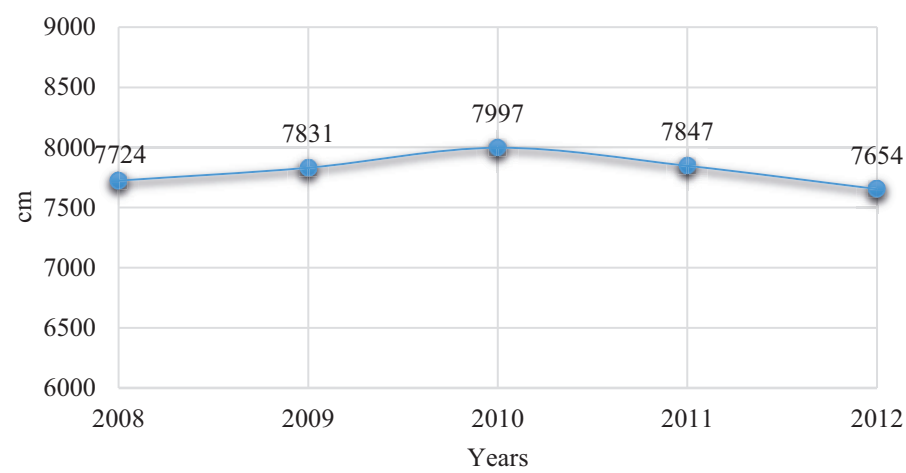

Fig. 6. Average annual level in Mingachevir reservoir for the period of 2008-2012 
The rising of the water level in the riverbed caused not only destruction of dams, but also resulted with the rising of groundwater in the area with little altitude difference to the riverbed, typically from one to several meters. Due to this low difference the settlements in the region are constantly under threat. Fluctuation between $0.5-1$ meters is sufficient for rising of groundwater level and inundation of residential settlements located close to the river bed.

Usually, Salyan and Neftchala districts were mostly affected regions by floodwaters, but during the 2010 flood, there were less inundations there than in other regions (Imishli, Saatli, Sabirabad). Just with the rising of groundwater, the areas close to the riverbed with little altitude difference were subject to the impact of groundwater.

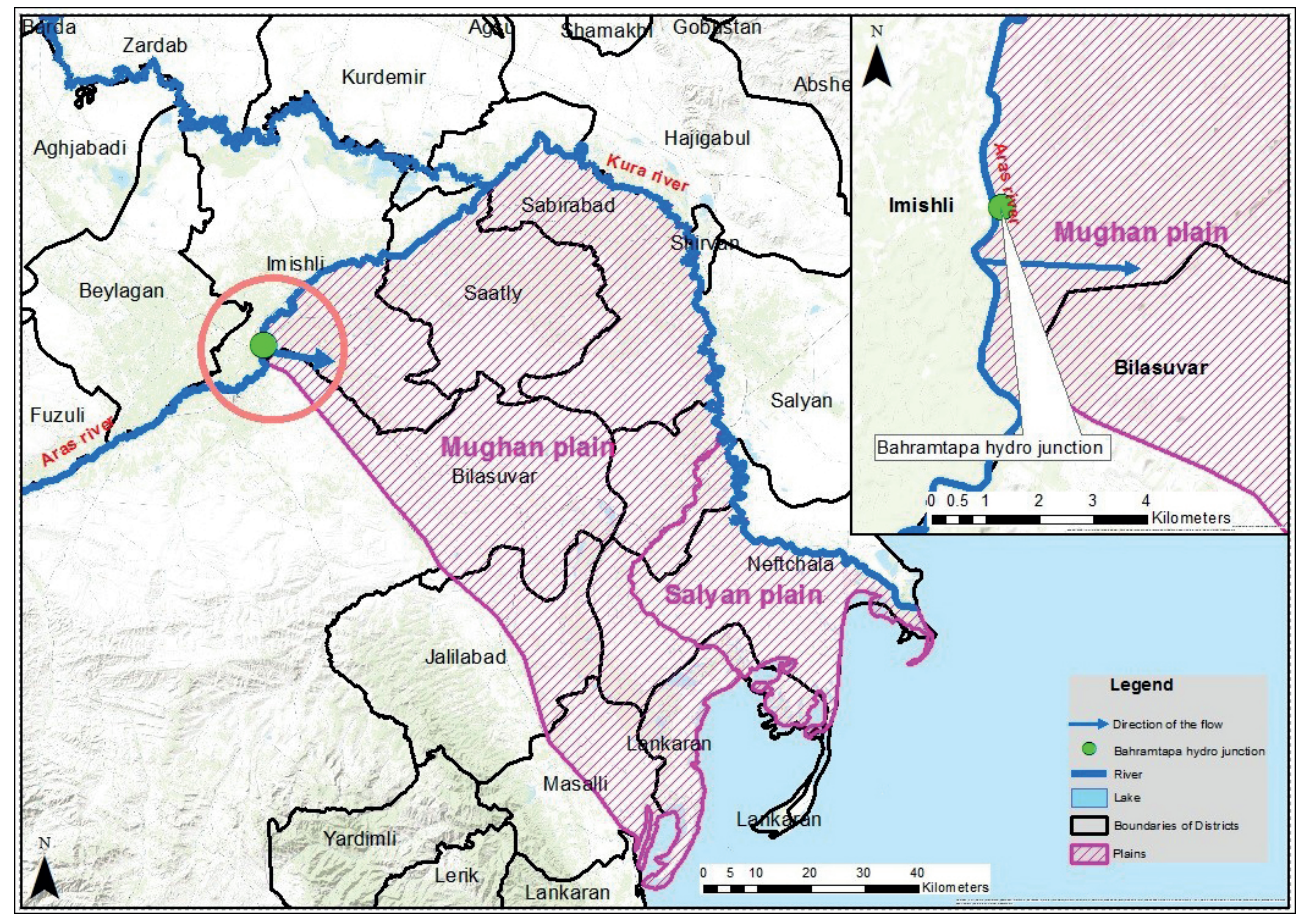

Fig. 7. Bahramtapa hydro junction

Besides from the natural flooding in 2010, some areas were inundated intentionally. Therefore, on the $31^{\text {st }}$ of May 2010, a new tributary from the Bahramtapa hydro junction on the Aras River in Imishli district was opened by The Ministry of Emergency Situations of the Republic of Azerbaijan to overcome the consequences of the flood, clean flooded areas from floodwaters, and to reduce the water level (Fig. 7). A new tributary directed the stream of the river to the Mughan plain on the right bank of the Aras River, flooding a large part of the plain. 


\section{Materials and Methods}

During the 2010 flood, a map had been developed based on the data collected from the field surveys during the flood and archival materials of the State Committee of Land and Cartography (SCLC) the Republic of Azerbaijan [1] (Fig. 8). But, the map that was produced by SCLC reflected a period of a couple of days after the flood occurrence - from $26^{\text {th }}$ of May to $29^{\text {th }}$ of June.

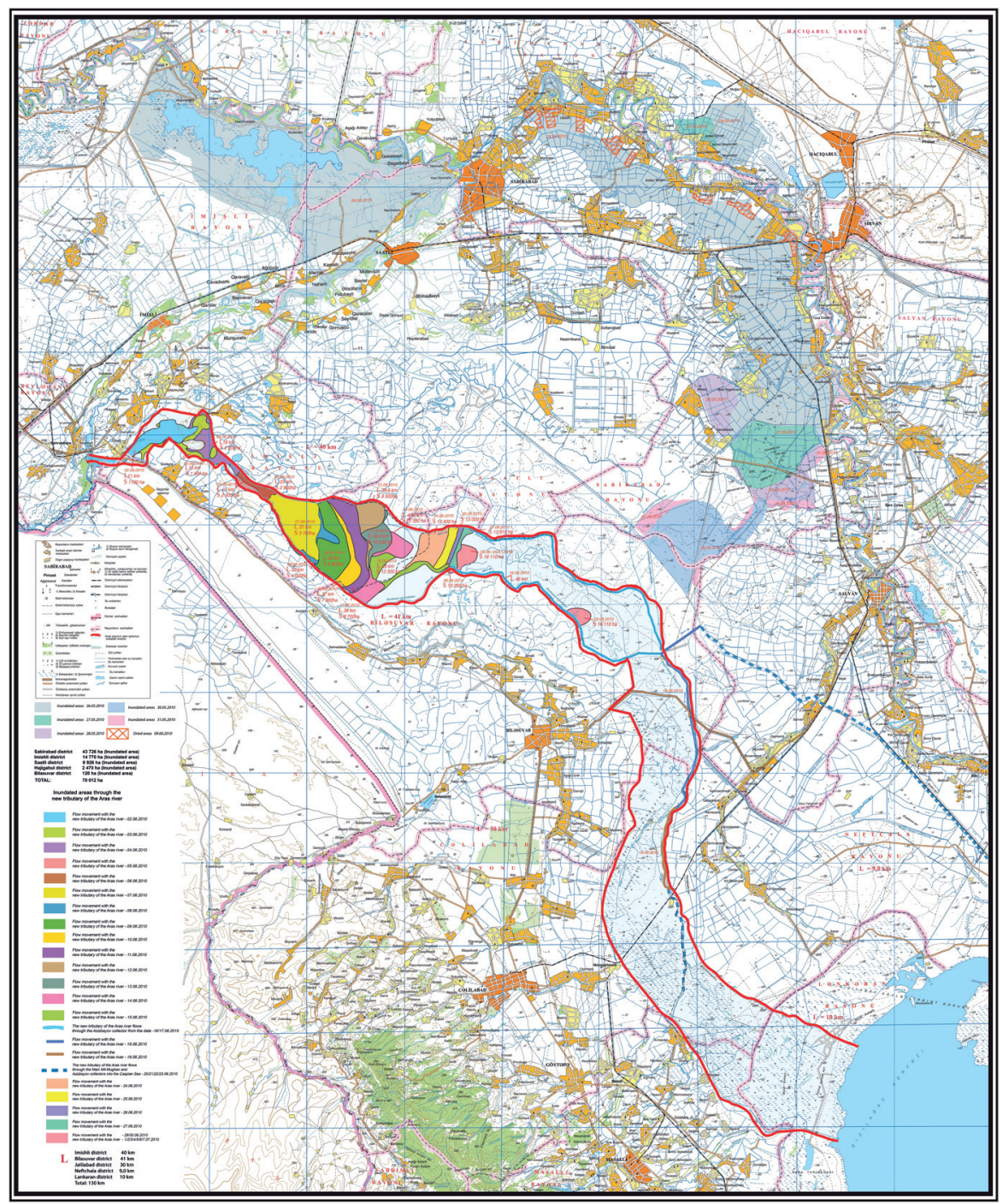

Fig. 8. Illustration of the inundated areas according to the Kura River flood and opening a new branch of the Aras River in 2010 on the map

Source: [1] 
According to the map, approximately 70,000 ha were inundated in several districts:

- Sabirabad district - 43,726 ha,

- Imishli district - 14,770 ha,

- Hajigabul district - 2470 ha,

- Bilasuvar district - 120 ha,

- Saatli district - 8926 ha,

The map that was prepared by SCLC was compiled according to the data of July 7, 2010. The map was compiled with the use of topographic maps in 1:100,000 scale as well. Generally, it was difficult to delineate precisely the extent of flooded areas during the flood. At that time it was almost impossible to transfer the field survey of the flooded areas into the map accurately due to the flood that covered the large area in a short time period.

In case of flood monitoring satellite data proved to be an effective method to get quick and precise overview of the flooded area [12], but unfortunately these data were not considered in the 2010 flood.

Currently, there are various satellites used by developed countries for different purposes and typically free of charge for scientific research. For this study, Landsat imagery available at the website of the U.S. Geological Survey (USGS) was used [8]. Landsat satellite data are freely available, with sufficient spatial resolution and offer a good opportunity to map flooded areas. In the search, images captured as close to the flooding date as possible, with low cloud cover were looked for. Images with better quality were acquired from Landsat 5 satellite and these images were selected for the study.

As a flood event is variable in space and time, it was difficult to determine the scope and mapping of the flood only with one satellite imagery. Therefore, several satellite images were used to investigate the 2010 flood. For that reason, 6 satellite images were obtained from the Landsat satellite that captured three different dates (Tab. 1). One acquisition was made before the flooding (September 2009) as it was important to capture the extent of water bodies the study area in normal conditions. One image was acquired during the flood (May 2010) and one immediately after (June 2010). For the analysis, satellite images provided as georeferenced AFR (multispectral) files were used.

Table 1. Metadata of the satellite images

\begin{tabular}{||c|c|c|c|c|c|c|}
\hline \multirow{2}{*}{$\begin{array}{c}\text { Data set } \\
\text { attribute }\end{array}$} & \multicolumn{7}{|c|}{ Attribute value } \\
\cline { 2 - 7 } & 1 & 2 & 3 & 4 & 5 & 6 \\
\hline \hline WRS Path & 167 & 167 & 167 & 167 & 167 & 167 \\
\hline WRS Row & 032 & 033 & 032 & 033 & 032 & 033 \\
\hline Date Acquired & $2009 / 09 / 26$ & $2009 / 09 / 26$ & $2010 / 05 / 24$ & $2010 / 05 / 24$ & $2010 / 06 / 09$ & $2010 / 06 / 09$ \\
\hline
\end{tabular}


The obtained satellite imagery was processed with ArcGIS software. Riverbeds of both rivers (the Kura and Aras) and inundated areas were manually delineated with the use of the appropriate tools of the program. Firstly, riverbeds of both rivers and water bodies (lakes) around the river were manually demarcated. Then flooded areas were manually delineated on both May and June 2010 satellite images. During the flood, floodwater overflowed protection dams and run into riverine water bodies, thus resulting in the expansion of the water bodies. Due to that reason, it was necessary to demarcate the riverine water bodies (lakes).

To identify the total flood area, delineated boundaries of 2010 May and June satellite images were combined using the "Merge tool" of the ArcGIS software. After merging of the total area, the delineated boundaries were extracted from the 2009 September image. The procedure (manual vectorisation) allowed us to reveal differences before and after the 2010 flood and to determine the flooded area.

In the next stage, merged boundaries from 2010 May and June images were divided with the "Clip tool" of ArcGIS software using the administrative (district) division in vector format. The flooded area in the 2010 flood (condition in May and June in merged form) could be then estimated for districts, using the September 2009 (pre-flood) image for comparison. Based on the percentage of flooded area, districts were grouped into mostly and partly affected ones.

\section{Results}

After delineation of the inundated areas and riverbeds for both rivers based on imageries that were acquired from the Landsat 5 satellite, the extent of the flooded areas (totally 127436 ha for May and June) was revealed (Fig. 9).
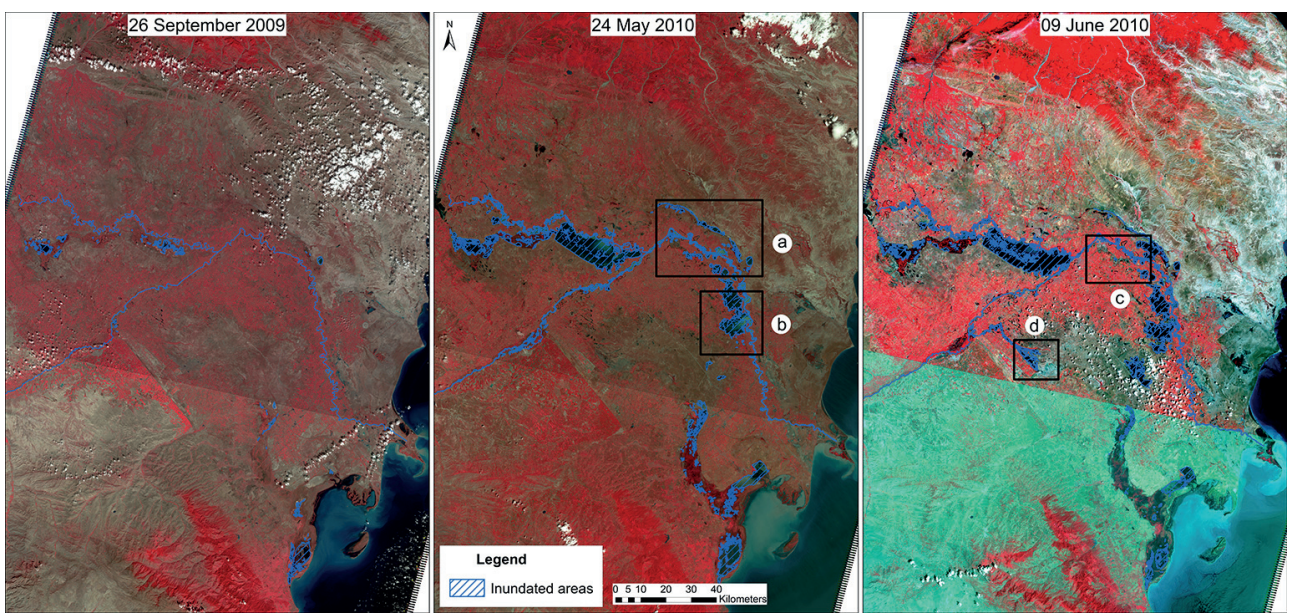

Fig. 9. Results of LANDSAT satellite data

Source: [8] 
Some inundated areas were selected for the comparative analysis of the two maps (Fig. 10).

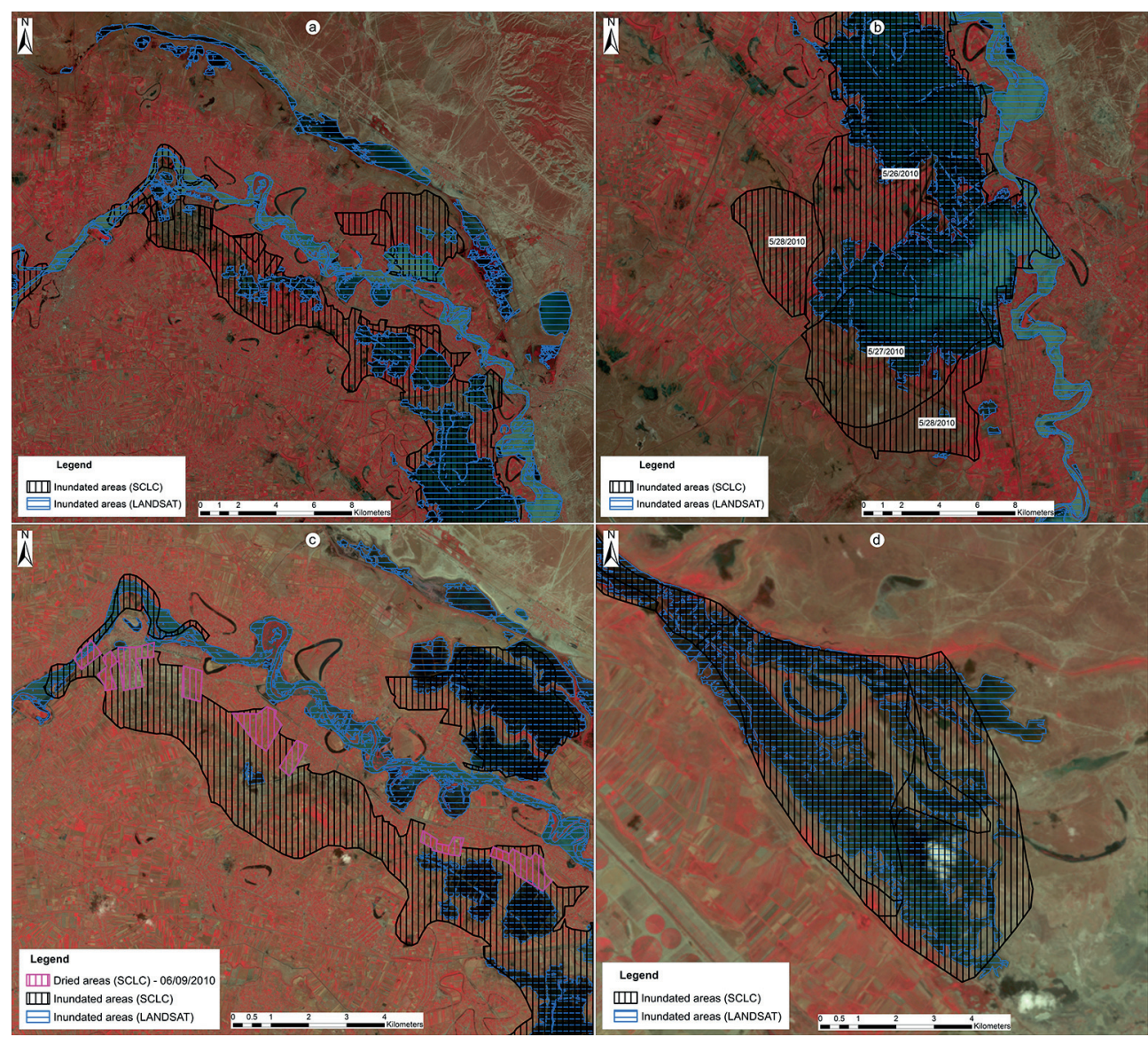

Fig. 10. Comparative maps of the 2010 flood

After comparing two delineated contours (the SCLC map and the May, June 2010 satellite images), the significant differences were revealed. For instance, in the selected area at Figure 10a in the map some inundated areas were not shown in the SCLC map at all. Although those areas were under flood waters already on the $24^{\text {th }}$ of May according to the satellite data, for the $26^{\text {th }}$ of May the SCLC map shows these areas as dry land. At Figure 10b, inundated areas on the satellite image were shown as flooded on the $27^{\text {th }}$ of May in the SCLC map. In other words, the extent of the flood in the $26^{\text {th }}$ of May on the SCLC map was smaller than the flood visible on the satellite image for $24^{\text {th }}$ of May. 
The other two selected areas were compared for the flood extent on the $9^{\text {th }}$ of June. For some inundated areas flood waters withdrew. It was achieved through the new tributary that was opened from the Bahramtapa hydro junction. According to the $9^{\text {th }}$ of June data, floodwaters withdrew in some inundated areas in the SCLC map. However, according to the contours that were obtained through satellite image, it is visible that floodwaters withdrew in a large part of those areas (Fig. 10c). In the next area (Fig. 10d), the direction of the flow for the $9^{\text {th }}$ of June from the new tributary that was opened from the Bahramtapa hydro junction was compared. Again, there were some slight differences between the data of the SCLC map and the satellite image for the same date (the $9^{\text {th }}$ of June): inundated areas were smaller in the map of SCLC.

According to the image of the $9^{\text {th }}$ of June, a large part of the territory of the Sabirabad district was released from the flood waters by directing the flow through the newly opened tributary from the Bahramtapa hydro junction. But the flood increased in other areas. Therefore, the new tributary from the Bahramtapa hydro junction was not effective enough to reduce the scale of the flooding. Several districts were affected by flood with various intensity. Sabirabad, Imishli and Saatli were heavily inundated districts, while Beylagan, Aghjabadi, Zardab, Shirvan cities, Salyan, Neftchala, Kurdamir, Hajigabul, Lankaran, Jalilabad and Bilasuvar districts were partly inundated districts (Fig. 11).

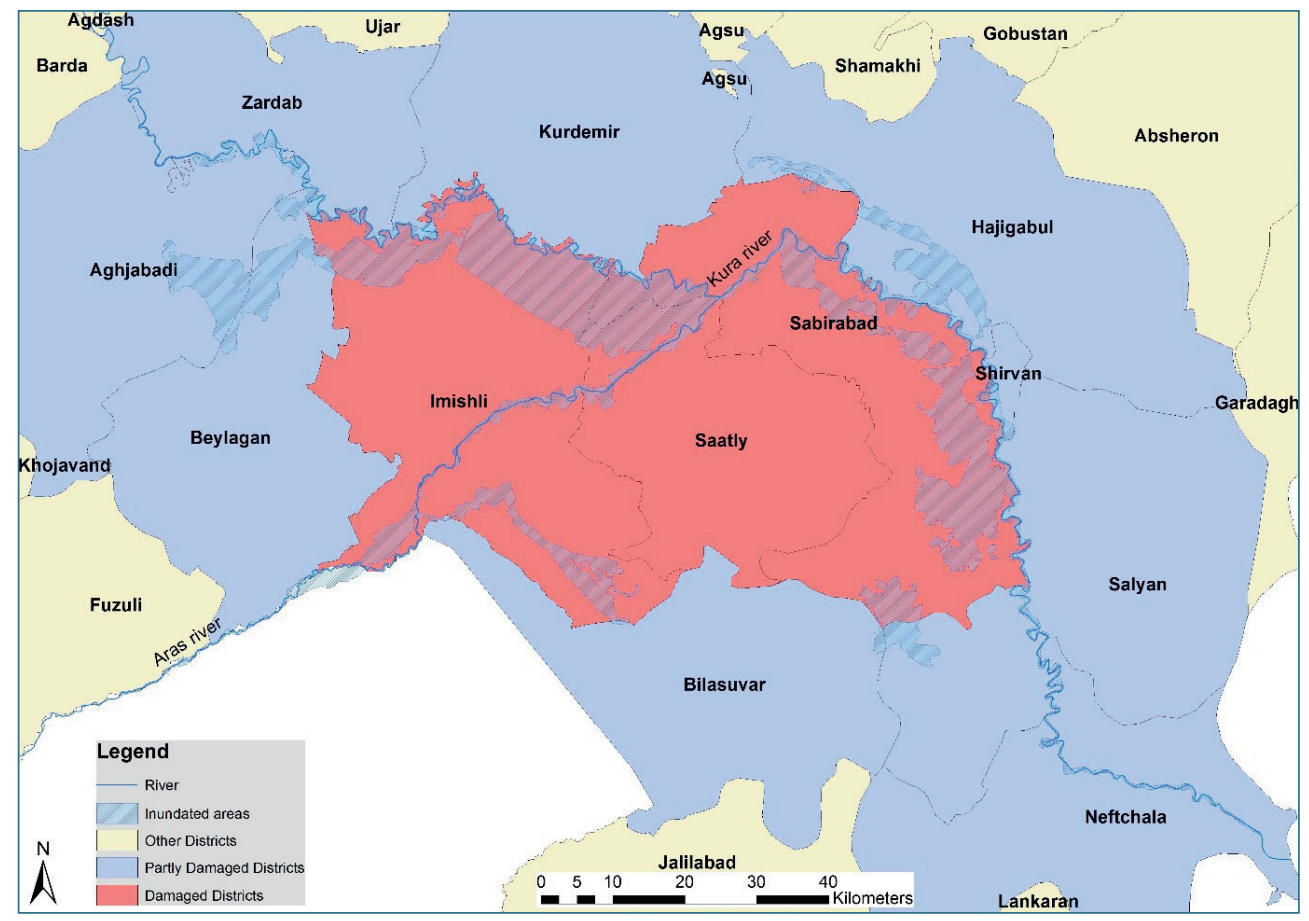

Fig. 11. Damaged districts in 2010 flood 


\section{Discussion}

The processing of Landsat satellite imageries through ArcGIS software significantly helped to investigate the flood extent in the study area. Generally, the time of acquisition of the satellite data does not coincide with the time of the flood peak which is related to the maximum inundation area [14]. The long lasting flood in the study area (approximately 1 month) allowed, however, to select enough good quality images to capture the flood extent variations between late May and early June, yet a full investigation of the flood in the study area does not seem to be possible based on a single sensor with moderate temporal frequency.

It should be noted that a study by Wang [23] indicated that it is possible to use successfully remotely sensed data acquired days after a peak flood to capture most of its extent. In their study, an image acquired nine days after the flood event captured over $90 \%$ of the flood extent identified in a survey carried out two days following the event. Such results indicate the usefulness of remotely sensed data acquired days after a flood peak in mapping flood consequences, reducing at the same time the requirements to have concurrent remotely sensed data [13].

\section{Conclusions}

The main subject of this paper was the investigation of the Kura River flood in 2010 using satellite imageries and GIS tools. Such a study was conducted for the first time. My investigation showed that the map that was produced by the responsible government agencies differed from the interpretation of satellite Landsat data in several locations. It was found that the opening of the new tributary from the river was not fully effective in order to reduce the extent of flooded areas.

In the study, the appropriateness of remote sensing in determining the flood extent was confirmed. Notably, for a relatively long flood event freely available Landsat data with a moderate temporal frequency proved to capture well flood dynamics. Combined with GIS tools, Landsat images helped to map flooded areas at two dates, and to estimate the magnitude of flooding, allowing to indicate completely and partly inundated areas during the flood. The method can be used not only for the determining of districts that were exposed to the flood, but also to identify inundated settlements and municipalities at the larger scale and resolution. In this way, remote sensing and GIS may support prevention measures and help to minimize flood damage at next flood events.

\section{Acknowledgements}

I would like to thank to the Head of Department of GIS, Cartography and Remote Sensing in the Institute of Geography and Spatial Management of the Jagiellonian University - Prof. Jacek Kozak, the Head of Research Institute of Hydrometeorology 
of Ministry of Ecology and Natural Resources - Prof. Mahmudov Rza, and to the Chief of Photogrammetry Department of State Aerogeodesic Enterprise of State Land and Cartography Committee of the Republic of Azerbaijan - Agil Ahmedov.

\section{References}

[1] Archival materials of the State Committee of Land and Cartography of Azerbaijan Republic, 2010.

[2] Aslanov H.G.: Ecogeographical problems of the downstream of the Kura River. Chashioghlu Press, Baku 2013 [Aslanov H.Q.: Kürün aşă̆ı axarının ekocoğrafi problemlari. Caşığlu Nəşriyyatı, Bakı 2013].

[3] Audisio C., Turconi L.: Urban floods: a case study in the Savigliano area (North-Western Italy). Natural Hazards and Earth System Sciences, vol. 11, 2011, pp. 2951-2964.

[4] Bababayli N.S., Imat F.M.: Eco-geographical zoning of the Aras River basin within the Turkey Republic. Works of Azerbaijan Geographical Society, 15, Baku 2010 [Bababəyli N.S., İmat F.M.: Araz çay hövzəsinin Türkiyə Respublikası daxilindəki ekocoğrafi rayonlaşması. Azərbaycan Coğrafiya cəmiyyətinin əsərləri, XV cild, Bak1 2010].

[5] Babakhanov N.A., Pashayev N.A.: Economic and socio-geographical study of Natural Disasters, Baku 2004 [Babaxanov N.A., Paşayev N.Ә.: Təbii fəlakətlarin iqtisadi va sosial-coğrafi öyranilmasi, Bakı 2004].

[6] Caucasus Environmental NGO Network (CENN) Report: Eco-migartion in Azerbaijan - trend, the dynamics and problems. Baku 2013 [Есо-мигращия в Азербайджане - тенденция, динамика и проблемы. Баку 2013].

[7] Committee on Earth Observation Satellites Disaster Management Support Group: The Use of Earth Observing Satellites for Hazard Support: Assessments $\mathcal{E}$ Scenarios. Final Report, NOAA, Dept. Commerce, USA, 2001.

[8] EarthExplorer, 2009-2010. [on-line:] http://earthexplorer.usgs.gov [access: 17.01.2015].

[9] Elimination of natural and man-made disasters, 2010, [on-line:] http://www. fhn.gov.az/index.php?aze/pages/33 [access: 20.05.2015].

[10] Eminov Z.N.: Geography. Chirag Press, Baku 2005 [Eminov Z.N.: Coğrafiya. Çıraq nəşriyyatı, Bakı 2005].

[11] Garayev V., Elma F.: Disaster Management System in Azerbaijan: The Case of Kura River Flood of 2010. [in]: Kapucu N., Liou K.T., Disaster and Development, Examining Global Issues and Cases, Springer, 2014, pp. 79-92.

[12] Haq M., Akhtar M., Muhammad S., Paras S., Rahmatullah J.: Techniques of Remote Sensing and GIS for flood monitoring and damage assessment: A case study of Sindh province, Pakistan. The Egyptian Journal of Remote Sensing and Space Sciences, vol. 15, 2012, pp. 135-141. 
[13] Ireland G., Volpi M., Petropoulos G.P.: Examining the capability of supervised machine learning classifiers in extracting flooded areas from Landsat TM Imagery: A case study from a Mediterranean Flood. Remote Sensing, vol. 7, 2015, pp. 3372-3399.

[14] Islam M.M., Sado K.: Development of flood hazard maps of Bangladesh using NOAA-AVHRR images with GIS. Hydrological Science Journal, vol. 45, 2000, pp. 337-355.

[15] Kuenzer C., Guo H., Huth J., Leinenkugel P., Li X., Dech S.: Flood Mapping and Flood Dynamics of the Mekong Delta: ENVISAT-ASAR-WSM Based Time Series Analyses. Remote Sensing, vol. 5, 2013, pp. 687-715.

[16] Lawal D.U., Matori A.-N., Hashim A.M., Chandio I.A., Sabri S., Balogun A.-L., Abba H.A.: Geographic Information System and Remote Sensing Applications in Flood Hazards Management: A Review. Research Journal of Applied Sciences, Engineering and Technology, vol. 3 (9), pp. 933-947.

[17] Mahmudov R.N.: Analysis of the hydrometeorological condition in Azerbaijan. Ziya, Baku 2015 [Mahmudov R.N.: Azərbaycanda hidrometeoroloji şaraitin tahlili. Ziya, Bakı 2015].

[18] Marfai M.A.: GIS modelling of river and tidal flood hazards in a waterfront city. Case study: Semarang City, Central Java, Indonesia. International Institute for Geo-Information Science and Earth Observation Enschede, The Netherlands, 2003 [thesis].

[19] Museyibov M.A.: Physical Geography of Azerbaijan. Maarif Press, Baku 1998 [Müseyibov M.A.: Azarbaycanın Fiziki Coğrafiyası. Maarif Nəşriyyat, Bakı 1998].

[20] Osorio J.D.G., Galiano S.G.G.: Development of a sub-pixel analysis method applied to dynamic monitoring of floods. International Journal of Remote Sensing, vol. 33, 2012, pp. 2277-2295.

[21] Pashayev E.P., Hasanov F.H.: History and development of the "Azdovsutaslayiha" Institute. Sharg-Garb Press, Baku 2010 [Paşayev E.P., Həsənov F.H.: "Azdövsutaslayiha" institutunun tarixi va inkişaf yolu. Bak1 2010].

[22] Stichter S.: The Caribbean Disaster Mitigation Project: Supporting Sustainable Responses to Natural Hazards. 1997, [on-line:] http://www.oas.org/cdmp/ document/papers/gisconf.htm [access: 02.04.2015].

[23] Wang Y.: Using Landsat 7 TM data acquired days after a flood event to delineate the maximum flood extent on a coastal floodplain. International Journal of Remote Sensing, vol. 25, 2004, pp. 959-974. 